\title{
Congenital Frontal Mature Dermoid Cyst: A Case Report
}

\author{
Mehmet Hakan Seyithanoglu1, Kazim Dogan2*, Meliha Gundag1, Serdar Cevik¹, \\ Seref Ozturk ${ }^{1}$, Tolga Turan Dundar ${ }^{1}$ \\ ${ }^{1}$ Department of Neurosurgery, Faculty of Medicine, Bezmialem Vakif University, Istanbul, Turkey \\ ${ }^{2}$ Department of Neurosurgery, Ardahan State Hospital, Ardahan, Turkey \\ Email: seyithan66@gmail.com, ${ }^{*}$ drkdogan@yahoo.com, melihagundag34@gmail.com, \\ dr.serdarcevik@gmail.com, serefozturko@yahoo.com, drtolga @hotmail.com
}

Received 3 August 2014; revised 3 September 2014; accepted 30 September 2014

Copyright (C) 2014 by authors and Scientific Research Publishing Inc.

This work is licensed under the Creative Commons Attribution International License (CC BY).

http://creativecommons.org/licenses/by/4.0/

c) (i) Open Access

\begin{abstract}
Dermoid cysts are uncommon congenital or acquired developmental cystic malformations that were usually seen in the midline of frontal region and the anterior fontanel. Congenital forms develop from the remnants of the epithelium or ectodermal membranous bone growth line. We report here a case of a congenital frontal dermoid cyst that should be considered in the differential diagnosis of lipoma and neurofibroma. Dermoid cysts should be considered in the differential diagnosis of all nodular cyst-like lesions in the head and neck region. Early recognition and accurate diagnosis by means of Computerized Tomography scan or Magnetic Resonance Imaging facilitate successful treatment.
\end{abstract}

\section{Keywords}

Dermoid Cyst, Congenital, Surgical Procedure, Operative

\section{Introduction}

Dermoid cyst is a cystic teratoma that contains developmentally mature skin complete with hair follicles and sweat glands, sometimes clumps of long hair, and often pockets of sebum, blood, fat, bone, nails, teeth, eyes, cartilage, and thyroid tissue [1]. Dermoid cysts are uncommon congenital or acquired developmental cystic malformations that were usually seen in the midline of frontal region and the anterior fontanel [2]. Congenital forms develop from the remnants of the epithelium or ectodermal membranous bone growth line. We report here a case of a congenital frontal dermoid cyst.

\footnotetext{
${ }^{*}$ Corresponding author.
}

How to cite this paper: Seyithanoglu, M.H., Dogan, K., Gundag, M., Cevik, S., Ozturk, S. and Dundar, T.T. (2014) Congenital Frontal Mature Dermoid Cyst: A Case Report. Open Journal of Modern Neurosurgery, 4, 186-189. 


\section{Case Report}

1-year-old boy admitted to our department with the complaints of the growing swelling in the midline of frontal region. Neurological and physical examination was unremarkable and anterior fontanelle nearly closed. Computerized Tomography (CT) scan and Magnetic Resonance Imaging (MRI) revealed a bone eroded, $3 \times 3.5 \mathrm{~cm}$ sized lesion in front of the midline of the anterior fontanelle (Figure 1 and Figure 2). The relationship between lesion and sagittal sinus was assessed and there was no connection between them. The patient was operated with the prediagnosis of dermoid cyst. The cystic lesion was completely circumscribed and excised without any tearing. Bone erosion was found at the bottom of the cyst (Figure 3).

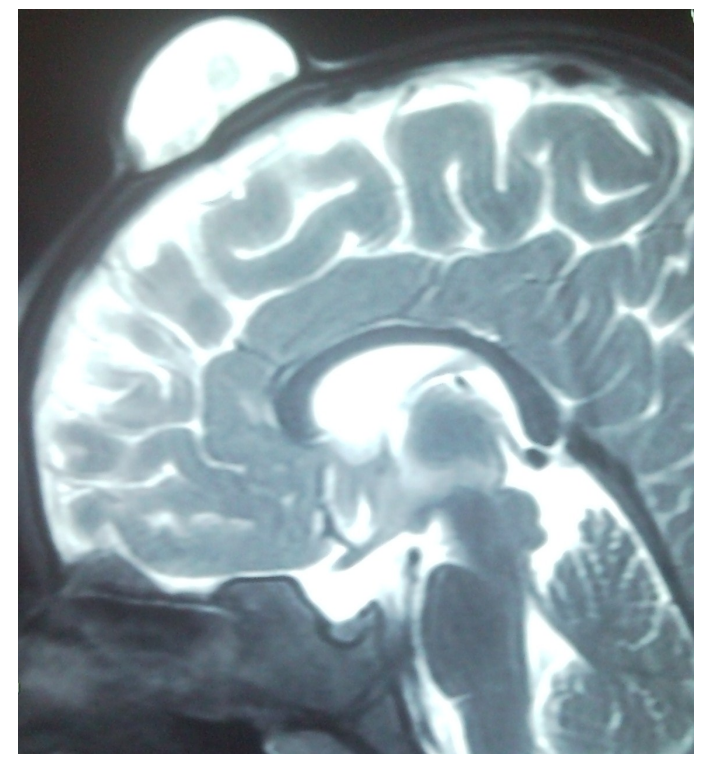

Figure 1. Magnetic Resonance Imaging (MRI) revealed a bone eroded, $3 \times 3.5 \mathrm{~cm}$ sized lesion in front of the midline of the anterior fontanelle.

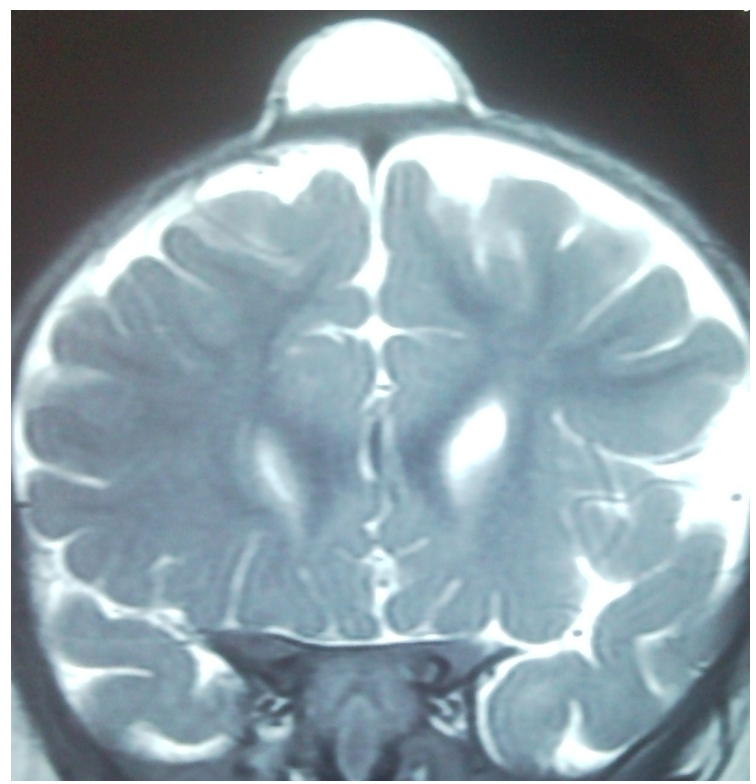

Figure 2. Magnetic Resonance Imaging (MRI) revealed a bone eroded, $3 \times 3.5 \mathrm{~cm}$ sized lesion in front of the midline of the anterior fontanelle. 


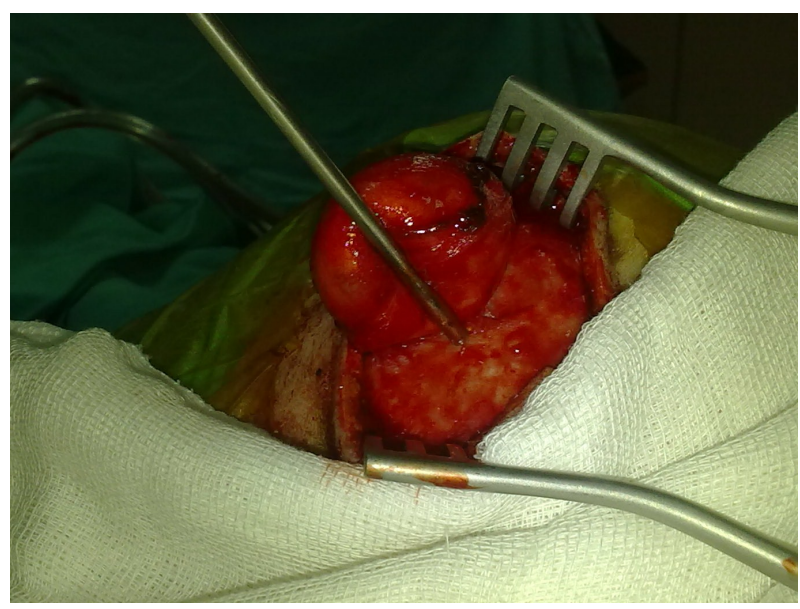

Figure 3. The cystic lesion was completely circumscribed and excised without any tearing. Bone erosion was found at the bottom of the cyst.

\section{Discussion}

Adeloye and Xu X.L. described this malformation clearly [3]. Dermoid cyst is a benign cystic teratoma that contains developmentally mature skin complete with hair follicles and sweat glands, sometimes clumps of long hair, and often pockets of sebum, blood, fat, bone, nails, teeth, eyes, cartilage, and thyroid tissue [1]. The cyst fluid should be clear or yellow color. The content of cyst fluid is composed of potassium chloride, sodium and glucose. Dermoid cysts occur as a result of a failure of ectoderm development in the third and fifth week of embryogenesis [4].

MRI and CT scan are most effective imaging methods to demonstrate the intracranial or extracranial location of the cyst and relationship between bone tissue and in differential diagnosis. Dermoid cysts should be included in the differential diagnosis of all nodular cyst-like lesions in the head and neck region such as encephalocele, meningocele, hemangioma, lipoma, hematoma, sebaceous cyst, pilonidal cyst and sinus pericranii. In our case cystic lesion was on the extracranial location and MRI and CT scan revealed a bone eroded, $3 \times 3.5 \mathrm{~cm}$ sized lesion in front of the midline of the anterior fontanelle. The relationship between lesion and sagittal sinus was assessed and there was no connection between them.

Bartlett et al. defined a treatment algorithm based on the potential extension of the lesions to the contiguous structures. They found that the frontotemporal dermoid cysts with definable margins are superficial, slow-growing masses that can be excised, preferably by a lid crease incision [5]. We used this frontal incision and the cystic lesion was completely circumscribed and excised without any tearing.

\section{Conclusion}

Dermoid cysts should be considered in the differential diagnosis of all nodular cyst-like lesions in the head and neck region. Early recognition and accurate diagnosis by means of CT scan or MRI facilitate successful treatment.

\section{Disclosure}

The authors report no conflict of interest concerning the materials or methods used in this study or the findings specified in this paper. We have no source or support on this study.

\section{References}

[1] New, G.B. and Erich, J.B. (1937) Dermoid Cyst of the Head and Neck. Surgery, Gynecology Obstetrics, 65, 48-56.

[2] Pryor, S.G., Lewis, J.E., Weaver, A.L. and Orvidas, L.J. (2005) Pediatric Dermoid Cysts of the Head and Neck. Otolaryngology-Head and Neck Surgery, 132, 938-942. http://dx.doi.org/10.1016/j.otohns.2005.03.005

[3] Adeloye, A. and Odeku, E.L. (1971) Congenital Subgaleal Cysts over the Anterior Fontanelle in Nigerians. Archives of 
Disease in Childhood, 46, 95-98.

[4] Wong, T.T., Wann, S.L. and Lee, L.S. (1986) Congenital Dermoid Cyst of the Anterior Fontanelle in Chinese Children. Child's Nervous System, 2, 175-178. http://dx.doi.org/10.1007/BF00706806

[5] Bartlett, S.P., Lin, K.Y., Grossman, R. and Katowitz, J. (1993) The Surgical Management of Orbitofacial Dermoids in the Pediatric Patient. Plastic and Reconstructive Surgery, 91, 1208-1215.

http://dx.doi.org/10.1097/00006534-199306000-00005 
Scientific Research Publishing (SCIRP) is one of the largest Open Access journal publishers. It is currently publishing more than 200 open access, online, peer-reviewed journals covering a wide range of academic disciplines. SCIRP serves the worldwide academic communities and contributes to the progress and application of science with its publication.

Other selected journals from SCIRP are listed as below. Submit your manuscript to us via either submit@scirp.org or Online Submission Portal.
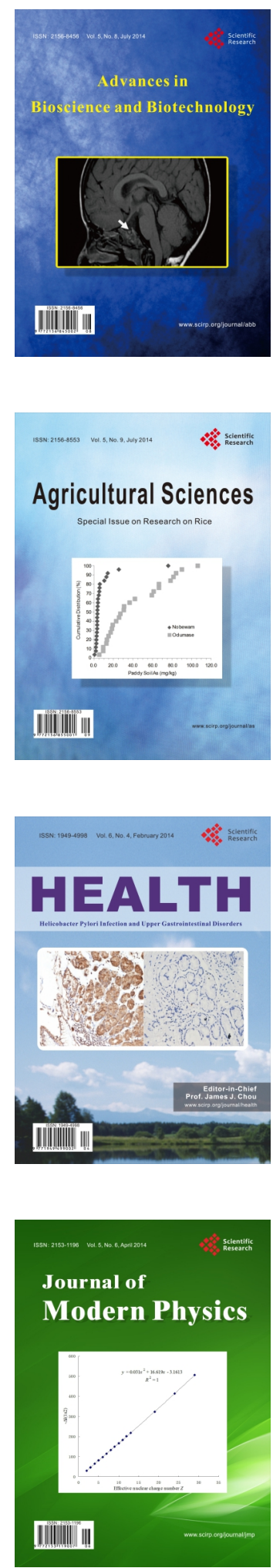
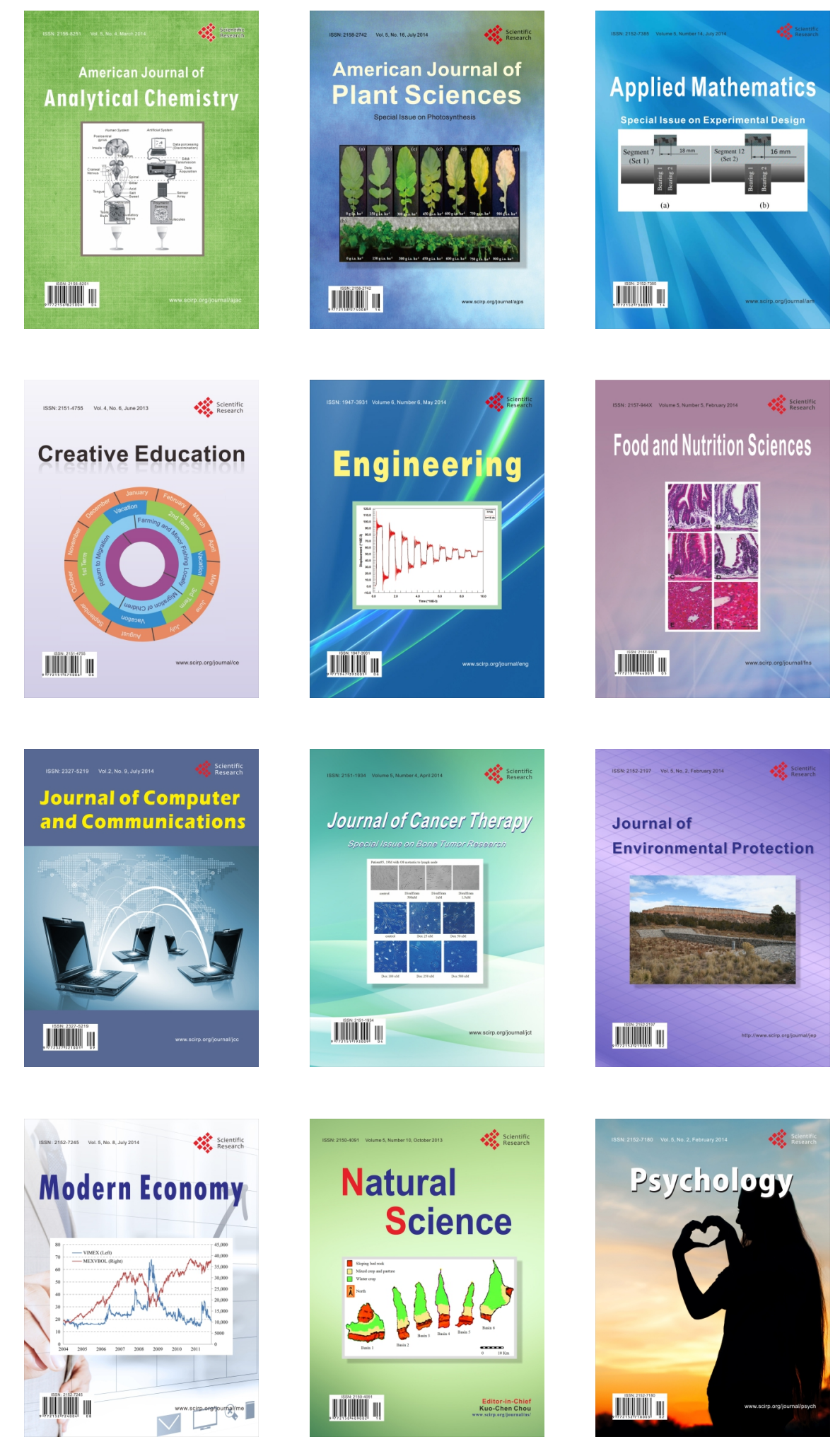